\title{
Effect of daminozide and flurprimidol on growth, flowering and bulb yield of Eucomis autumnalis (Mill.) Chitt.
}

Piotr Salachna*, Agnieszka Zawadzińska

Department of Horticulture

West Pomeranian University of Technology in Szczecin Papieża Pawła VI 3, 71-459 Szczecin, Poland

\begin{abstract}
Eucomis autumnalis (Mill.) Chitt., commonly known as pineapple lily, is a new ornamental pot plant with great marketing potential. This work evaluated the effects of two gibberellin synthesis inhibitors (daminozide and flurprimidol) applied as commercial plant growth regulators (PGRs) B-Nine and Topflor on the growth, flowering, and bulb yield in E. autumnalis. The PGRs were applied three times as substrate drenches or foliar sprays at the concentration of $15 \mathrm{mg} \mathrm{dm}^{-3}$ (flurprimidol) or $4250 \mathrm{mg} \mathrm{dm}^{-3}$ (daminozide). Plant growth was restricted only by flurprimidol, particularly when it was applied as substrate drenches. Plant height was reduced by $48 \%$ at anthesis and by $38 \%$ at flower senescence, compared to the untreated control. Regardless of the application method, flurprimidol increased the leaf greenness index (SPAD) and bulb weight. Daminozide treatments were ineffective in controlling plant height and negatively influenced bulb weight. Foliar sprays of daminozide increased the length of inflorescences and the number of flowers per inflorescence.
\end{abstract}

Key words: B-Nine, growth retardant, pineapple lily, Topflor

\section{INTRODUCTION}

The genus Eucomis L'Hér. consists of 12 species of bulbous plants (Asparagaceae family) endemic to the summer rainfall areas of South Africa (Zonneveld and Duncan 2010). The plants produce decorative raceme inflorescences composed of numerous star-shaped flowers that are transformed into decorative capsule fruits after pollination. A tuft of green bracts is located at the top of the inflorescence, which is why this plant is commonly known as pineapple lily or pineapple flower. Eucomis autumnalis (Mill.) Chitt. is a particularly interesting species with green-white, pleasantly fragrant flowers. This ornamental crop is grown mainly for cut flowers and flowering potted-plants for indoor display (Luria et al. 2011).
E. autumnalis has long been used as a natural medicine due to its high biological activity (BisiJohnson et al. 2011, Masondo et al. 2014a, Salachna et al. 2015a). Unfortunately, acquiring bulbs from natural habitats poses a threat of extinction of the entire E. autumnalis population (Taylor and van Staden 2001, Ndhlala et al. 2012). Moreover, the natural propagation rate of this species through offsets is very low (Fitchet and van de Venter 1988). Therefore, the use of various compounds that stimulate and accelerate bulb production in E. autumnalis is important (Masondo et al. 2014b, Salachna et al. 2015b).

The main problem in pineapple lily cultivation under cover is excessive growth of flower stems that often bend or break (Filios and Miller 2013).

\footnotetext{
*Corresponding author.

Tel.: +91 44963 59;

e-mail: piotr.salachna@zut.edu.pl (P. Salachna).
} 
Plant quality is also decreased by excessively long leaves growing from bulbs, especially under high temperatures or low light conditions (De Hertogh and Le Nard 1993). A solution to this is the use of plant growth regulators (PGRs) to control plant size (Whipker et al. 2011, Carlson et al. 2015). In addition, PGRs can also affect other processes, such as flowering and bulb reproduction (Pobudkiewicz and Treder 2006, Taha 2012). However, plant response to PGRs may differ even within the same species and depends on the retardant type, dose and application method, frequency of application, age of plant, nutritional status and environmental conditions (Basra 2000, Barett and Bartuska 2010, Salachna and Zawadzińska 2013, Sprzączka and Laskowska 2013, Ahmad et al. 2015). A literature search on the impact of retardants on the growth of pineapple lily returned reports for only three cultivars. Carlson et al. (2015) recommend the use of paclobutrazol at $0.5-2.0 \mathrm{mg} / \mathrm{pot}$, uniconazole at $0.25-2.0 \mathrm{mg} / \mathrm{pot}$ or flurprimidol at $0.5-1.0 \mathrm{mg} /$ pot for 'Leia' (hybrid of E. zambesiaca Baker and $E$. vandermerwei I.Verd.) forced in the greenhouse. Filios and Miller (2013) succeeded in limiting the growth of E. comosa 'Innocennce' and 'Tugela Ruby' grown under normal greenhouse conditions by applying paclobutrazol at 4.0 and $8.0 \mathrm{mg} /$ pot and flurprimidol at 2.0, 4.0 and $8.0 \mathrm{mg} /$ pot. So far, there have been no data on the use of growth retardants in the cultivation of E. autumnalis as potted plants. Thus, the present study aimed to investigate the effects of flurprimidol and daminozide on the growth, flowering and bulb yield of E. autumnalis.

\section{MATERIAL AND METHODS}

The study was conducted in two seasons, in an unheated plastic tunnel that belongs to the Department of Horticulture, West Pomeranian University of Technology in Szczecin $\left(53^{\circ} 25^{\prime} \mathrm{N}\right.$, $14^{\circ} 32^{\prime}$ E). The bulbs of Eucomis autumnalis used in the experiment were obtained every season from Holland. Bulbs with a circumference of $16-18 \mathrm{~cm}$ and average weight of $81-86 \mathrm{~g}$ were stored in the dark at $8-10^{\circ} \mathrm{C}$ until planting. After treatment with fungicides (Topsin $0.7 \%$ and Kaptan $1 \%$ ), the bulbs were planted $3 \mathrm{~cm}$ below the substrate surface in round plastic pots (18-cm diameter) in mid-April in both growing seasons (2013 and 2014). The growing medium used was a peat substrate of $\mathrm{pH} 6.5$ that contained Hydrocomplex fertilizer $\left(5 \% \mathrm{~N}-\mathrm{NO}_{3}, 7 \%\right.$ $\mathrm{N}-\mathrm{NH}_{4}, 11 \% \mathrm{P}_{2} \mathrm{O}_{5}, 18 \% \mathrm{~K}_{2} \mathrm{O}, 2.7 \% \mathrm{MgO}, 8 \% \mathrm{~S}$, $0.015 \% \mathrm{~B}, 0.2 \% \mathrm{Fe}, 0.02 \% \mathrm{Mn}$, and $0.02 \% \mathrm{Zn}$ ) at a dose of $5 \mathrm{~g} \mathrm{dm}^{-3}$. The pots were placed on tables
$60 \mathrm{~cm}$ above the ground. Two commercial retardants were tested: Topflor 015 SL (SePRO Corporation, USA) containing $1.5 \%$ flurprimidol [alpha-(1methylethyl)-alpha-(4-(trifluoromethoxyphenyl)-5pyrimidinemethanol] and B-Nine $85 \mathrm{SG}$ (Chemtura, Netherlands) containing $85 \%$ daminozide (4-(2,2-dimethylhydrazinyl)-4-oxobutanoic acid). The PGRs at the concentration of $15 \mathrm{mg} \mathrm{dm}^{-3}$ (flurprimidol) or $4250 \mathrm{mg} \mathrm{dm}^{-3}$ (daminozide) were applied on 3, 10 and 17 June 2013 and on 2, 9 and 16 June 2014. Two methods of application were used: substrate drenches $(100 \mathrm{ml}$ solution per pot, i.e. flurprimidol at $1.5 \mathrm{mg}$ per pot and daminozide at $425 \mathrm{mg}$ per pot for each application) or foliar sprays $(30 \mathrm{ml}$ solution per plant, i.e. flurprimidol at $0.46 \mathrm{mg}$ per plant and daminozide at $127 \mathrm{mg}$ per plant for each application). Control plants were not treated with PGRs. The plants were grown under the natural photoperiod. Mean monthly air temperatures inside the tunnel were $(2013 / 2014)$ : April $\left(11.7^{\circ} \mathrm{C} / 15.1^{\circ} \mathrm{C}\right)$, May $\left(17.9^{\circ} \mathrm{C} / 18.9^{\circ} \mathrm{C}\right)$, June $\left(20.3^{\circ} \mathrm{C} / 19.7^{\circ} \mathrm{C}\right)$, July $\left(22.4^{\circ} \mathrm{C} / 24.1^{\circ} \mathrm{C}\right)$, August $\left(20.0^{\circ} \mathrm{C} / 19.6^{\circ} \mathrm{C}\right)$, and September $\left(16.7^{\circ} \mathrm{C} / 18.3^{\circ} \mathrm{C}\right)$.

The number of days from planting the bulbs to anthesis was recorded. When the first row of flowers had opened on the inflorescence, the following parameters were measured: total plant height (from the substrate level to the top of the inflorescence), total number of leaves per plant, length of the central leaf in a rosette, and width of the central leaf between its extremities. Leaf greenness index was measured with a SPAD-502 Chlorophyll Meter (Minolta, Japan). Mean SPAD value was calculated based on three readings of three leaves from each plant. Percentage of marketable plants was determined as the number of potted plants with a high ornamental value (compact habit, no visible defects, presence of at least one inflorescence). When the flowering had finished and ornamental fruits had been produced (29-37 days after anthesis), total plant height, inflorescence length (without the scape), and diameter of the scape (under the inflorescence) were recorded. The number of flowers per inflorescence was counted according to the number of pedicels in the inflorescences. After bulb harvesting, the number and total weight of bulbs per plant were determined.

The study was designed as a fully randomized univariate experiment in four replications comprising five plants each. The measurements were statistically verified using the analysis of variance and Statistica 12 software (Statsoft, Poland). Due to insignificant differences between 
the years, data are presented as the mean of two growing seasons.

\section{RESULTS AND DISCUSSION}

The results of the study showed that only flurprimidol significantly reduced plant height (Tab. 1). The plants drenched or sprayed with flurprimidol were shorter by $48 \%$ and $21 \%$, respectively, at the beginning of anthesis, and by $38 \%$ and $22 \%$ at flower senescence, compared with the control. Flurprimidol applied as substrate drenches was more effective than foliar sprays. Similar results had been obtained by Filios and Miller (2013), who proved that flurprimidol drenches $(2.0 \mathrm{mg} / \mathrm{pot})$ caused height reduction by $31 \%$ and $29 \%$ in Eucomis comosa 'Innocence' and E. comosa 'Tugela Ruby', respectively. Daminozide foliar sprays or substrate drenches were ineffective in controlling the height, neither at the beginning nor towards the end of the flowering stage (Tab. 1). This was consistent with the report by Pobudkiewicz and Treder (2006), who compared the effects of flurprimidol and daminozide on the oriental lily 'Mona Lisa' and found that plant growth was inhibited only by flurprimidol. These two retardants have different mechanisms of action. Flurprimidol belongs to inhibitory compounds with an $\mathrm{N}$-containing heterocycle and inhibits gibberellin production (specifically GA, early in the isoprenoid pathway by blocking the oxidation of ent-kaurene to ent-kaurenoic acid (Grossman 1992, Sun and Kamiya 1994). Daminozide inhibits the late stages of GA biosynthesis. It blocks 3ß-hydroxylation, thereby inhibiting the formation of highly active GAs from inactive precursors (Rademacher 2000).

The use of the investigated retardants did not change the number of leaves (data not shown), but substantially affected leaf width and length (Tab. 1). The plants grown with flurprimidol drenching had narrower leaves compared with those sprayed with daminozide. Moreover, the leaves of the plants drenched or sprayed with flurprimidol were significantly shorter than in the control, by respectively $24 \%$ and $19 \%$. Similar results had been reported by Kapczyńska and Malik (2016), who demonstrated that soaking bulbs of two Lachenalia cultivars in flurprimidol at $30 \mathrm{mg} \mathrm{L}^{-1}$ shortened the length of the first and second leaf by, respectively, $18 \%$ and $17 \%$ in 'Ronina' and by $23 \%$ and $23 \%$ in 'Rupert' Plants with shorter leaves are easier to pack and transport. Also, their density per square meter of cultivation space may be higher, thus making the production more cost-effective (Rademacher 2015). During the experiment, no symptoms of leaf phytotoxicity were observed after flurprimidol or daminozide application. The plants treated with flurprimidol had a significantly higher leaf greenness index than the control plants and plants treated with daminozide (Tab. 1). More intense coloration of the leaves after flurprimidol treatment was also observed in the oriental lily 'Mona Lisa' (Pobudkiewicz and Treder 2006) and Giant Chincherinchee (Salachna and Zawadzińska 2013). Flurprimidol treatment may increase the chlorophyll content and thus enhance leaf greenness (Gaussoin et al. 1997, Zawadzińska et al. 2013). The higher leaf greenness index of plants treated with flurprimidol (Tab. 1) means that the chlorophyll leaf content is higher, and this can improve plant quality and appearance.

The number of days from planting the bulbs to the beginning of anthesis was affected by the type of retardant and its application method (Tab. 2). The plants drenched with flurprimidol or sprayed with daminozide began flowering 3 days later than the control ones. However, there were no differences in flowering date between the plants sprayed with flurprimidol or drenched with daminozide and the control. Carlson et al. (2015) had proved

Table 1. Effects of flurprimidol and daminozide on height and leaf characteristics of Eucomis autumnalis

\begin{tabular}{|c|c|c|c|c|c|}
\hline Treatment & $\begin{array}{l}\text { Plant height } \\
\text { at anthesis } \\
(\mathrm{cm})\end{array}$ & $\begin{array}{l}\text { Plant height } \\
\text { at flower } \\
\text { senescence } \\
\text { (cm) }\end{array}$ & $\begin{array}{l}\text { Leaf width } \\
\text { (cm) }\end{array}$ & $\begin{array}{l}\text { Leaf length } \\
\quad(\mathrm{cm})\end{array}$ & $\begin{array}{c}\text { Greenness index } \\
\text { of leaves } \\
\text { (SPAD) }\end{array}$ \\
\hline Control & $30.7 \mathrm{a}$ & $34.3 \mathrm{a}$ & $5.30 \mathrm{ab}$ & $23.7 \mathrm{a}$ & $31.1 \mathrm{~b}$ \\
\hline Flurprimidol drenches & $16.1 \mathrm{c}$ & $21.3 \mathrm{c}$ & $4.68 \mathrm{~b}$ & $18.1 \mathrm{~b}$ & $34.6 \mathrm{a}$ \\
\hline Flurprimidol foliar sprays & $24.1 \mathrm{~b}$ & $26.9 \mathrm{~b}$ & $4.94 \mathrm{ab}$ & $19.3 \mathrm{~b}$ & $35.7 \mathrm{a}$ \\
\hline Daminozide drenches & $31.0 \mathrm{a}$ & $34.6 \mathrm{a}$ & $5.05 \mathrm{ab}$ & $22.6 \mathrm{a}$ & $32.2 \mathrm{~b}$ \\
\hline Daminozide foliar sprays & $29.4 \mathrm{a}$ & $38.6 \mathrm{a}$ & $5.55 \mathrm{a}$ & $23.0 \mathrm{a}$ & $32.6 \mathrm{~b}$ \\
\hline Significance & $* *$ & $* *$ & $*$ & $* * *$ & $* *$ \\
\hline
\end{tabular}

Explanations: means marked with the same letter in a column do not differ significantly at $p \leq 0.05$ according to Duncan's New Multiple Range Test; ***: significant at $p \leq 0.05$, or 0.01 , respectively 
Table 2. Effects of flurprimidol and daminozide on the number of days to anthesis, inflorescence characteristics and percentage of marketable plants of Eucomis autumnalis

\begin{tabular}{lccccc}
\hline Treatment & $\begin{array}{c}\text { Days to } \\
\text { anthesis }\end{array}$ & $\begin{array}{c}\text { Inflorescence } \\
\text { length } \\
(\mathrm{cm})\end{array}$ & $\begin{array}{c}\text { Scape diameter } \\
(\mathrm{cm})\end{array}$ & $\begin{array}{c}\text { Number } \\
\text { of flowers per } \\
\text { inflorescence }\end{array}$ & $\begin{array}{c}\text { Marketable } \\
\text { plants } \\
(\%)\end{array}$ \\
\hline Control & $82 \mathrm{~b}$ & $19.1 \mathrm{~b}$ & $0.88 \mathrm{~b}$ & $75 \mathrm{ab}$ & $88 \mathrm{~b}$ \\
Flurprimidol drenches & $85 \mathrm{a}$ & $14.2 \mathrm{c}$ & $1.08 \mathrm{a}$ & $68 \mathrm{bc}$ & $90 \mathrm{~b}$ \\
Flurprimidol foliar sprays & $80 \mathrm{~b}$ & $16.1 \mathrm{c}$ & $0.81 \mathrm{~b}$ & $65 \mathrm{c}$ & $95 \mathrm{a}$ \\
Daminozide drenches & $80 \mathrm{~b}$ & $18.5 \mathrm{~b}$ & $0.73 \mathrm{~b}$ & $60 \mathrm{c}$ & $88 \mathrm{~b}$ \\
Daminozide foliar sprays & $85 \mathrm{a}$ & $21.5 \mathrm{a}$ & $0.88 \mathrm{~b}$ & $81 \mathrm{a}$ & $90 \mathrm{~b}$ \\
Significance & $* *$ & $*$ & $* *$ & $*$ & $*$ \\
\hline
\end{tabular}

Explanations: means marked with the same letter in a column do not differ significantly at $p \leq 0.05$ according to Duncan's New Multiple Range Test; ${ }^{*}{ }^{* *}$ : significant at $p \leq 0.05$, or 0.01 , respectively

that retardants slightly delayed flowering in the pineapple lily 'Leia'. Delayed flowering has also been observed in other geophytes after the application of a retardant (Whipker et al. 2011, Pobudkiewicz and Treder 2006, Sprzączka and Laskowska 2013, Salachna and Zawadzińska 2013, Kapczyńska and Malik 2016).

The obtained results revealed that foliar sprays of flurprimidol increased the percentage of marketable plants (Tab. 2). The quality of inflorescencedepended on the type of retardant and its application method. The plants drenched or sprayed with flurprimidol produced significantly shorter inflorescences (by $26 \%$ and $16 \%$, respectively), compared with the control ones (Tab. 2). The scape of the plants drenched with flurprimidol also had an increased diameter. The effects of daminozide depended on its application method. The plants sprayed with daminozide had the longest inflorescences with the greatest number of flowers. Those drenched with

\section{$\square$ control \\ $\square$ flurprimidol foliar sprays \\ $\square$ daminozide foliar sprays}

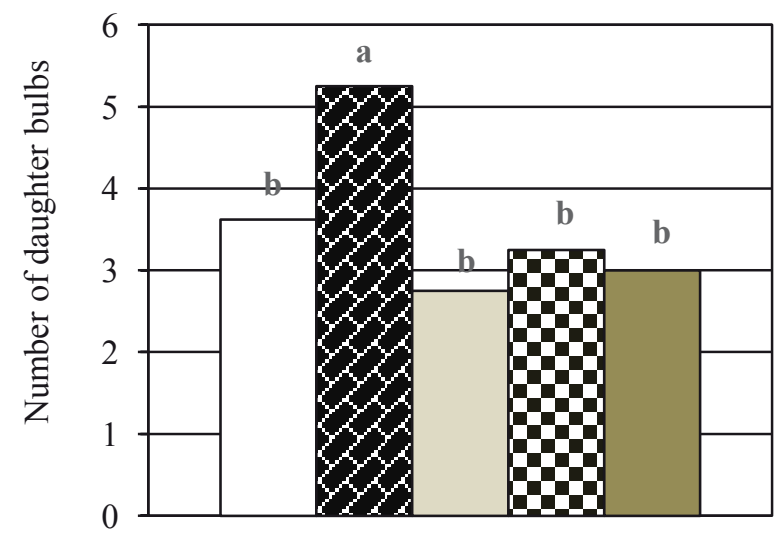

Figure 1. Effects of flurprimidol and daminozide on the number of daughter bulbs of Eucomis autumnalis. Means represented by columns marked with the same letter do not differ significantly at $p \leq 0.05$ according to Duncan's New Multiple Range Test

daminozide produced significantly fewer flowers per inflorescence compared with the control, but the number of flowers was similar to that produced by the plants sprayed with flurprimidol. In some species, daminozide can increase the number of flowers (Kazaz et al. 2010, Hashemabadi et al. 2012) and its foliar application is more effective than substrate drenching (Grossman 1992).

The plants drenched with flurprimidol produced significantly more daughter bulbs than the plants in the other treatments (Fig. 1). Moreover, the bulbs produced by the plants drenched or sprayed with flurprimidol had a significantly higher weight compared with the control, by respectively $12 \%$ and 20\%. A slight reduction in weight of the bulbs was observed after treatment with daminozide (Fig. 2). The effect of plant growth regulators on bulb yield in E. autumnalis was ambiguous. This might be due to the fact that PGRs affect the balance of plant hormones in the treated plants and

$\square$ control

$\square$ flurprimidol foliar sprays

$\square$ daminozide foliar sprays

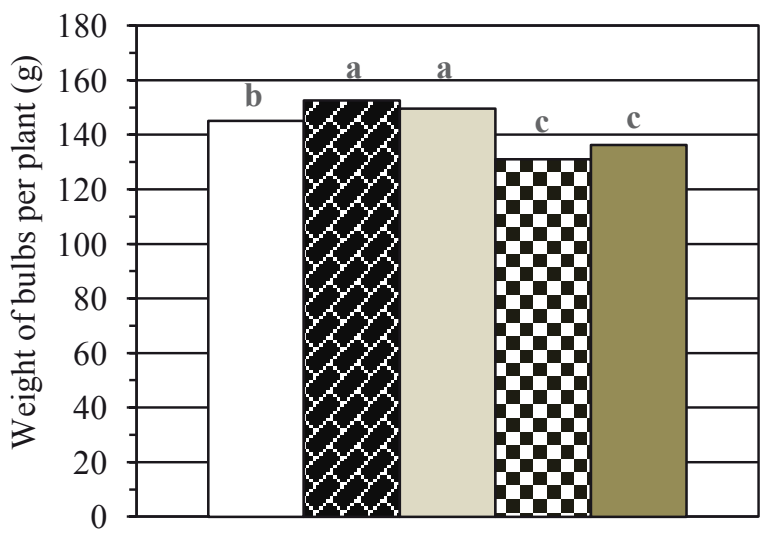

Figure 2. Effects of flurprimidol and daminozide on the weight of bulbs of Eucomis autumnalis. Means represented by columns marked with the same letter do not differ significantly at $p \leq 0.05$ according to Duncan's New Multiple Range Test 
promote, inhibit or otherwise modify the plant's physiological processes (Rademacher 2015). Ilczuk et al. (2005) had proved that flurprimidol used as a supplement in an in vitro medium increased the number of new bulblets per original bulb and the size of newly developed bulblets in Hippeastrum $\times$ chmielii. Zheng et al. (2012) demonstrated that the lily 'Sorbonne' treated with PGRs had higher levels of starch, sucrose and indole-3-acetic acid in the bulbs, which may stimulate the formation of new scales and bulb growth. The greater bulb weight of the plants treated with flurprimidol might be due to the mechanism of sink direction change. Restricted synthesis of gibberellins after flurprimidol application reduced not only plant height but also the number of flowers in the inflorescence and their length (Tab. 2). The assimilates produced in the leaves were transported probably in greater amounts to the developing bulbs than to the flowers. The stimulating effect of flurprimidol may improve the growth of daughter bulbs and shorten the time of growing up to the commercial size to produce flowers. Further work is required to assess the mechanism of the effects of PGRs on the distribution and concentration of endogenous growth substances within the bulb of E. autumnalis.

In summary, the results of this study seem to indicate high suitability of flurprimdiol as a plant growth regulator in E. autumnalis production. To obtain plants with the quality required by the potted crop market, the most effective treatment appears to be the application of flurprimdiol in foliar sprays. Drenches of flurprimdiol may be used to increase the number of daughter bulbs in E. autumnalis.

\section{CONCLUSIONS}

1. Flurprimidol foliar sprays or substrate drenches effectively improve plant shape expressed as more compact growth, improved leaf greenness index and higher bulb yield of E. autumnalis.

2. Daminozide was ineffective in controlling the height of Eucomis plants.

3. Foliar sprays of daminozide increased inflorescence length and the number of flowers per inflorescence.

\section{FUNDING}

This study was supported by the Polish Ministry of Science and Higher Education, within the project UPB 518-07-014-3176-02/18 ZUT.

\section{AUTHOR CONTRIBUTIONS}

All the authors contributed equally to this work. P.S. - designed and performed the experiments, analyzed the data and wrote the paper; A.Z. analyzed the data and wrote the paper.

\section{CONFLICT OF INTEREST}

Authors declare no conflict of interest.

\section{REFERENCES}

Ahmad I., Whipker B.E., Dole J.M., 2015. Flurprimidol preplant corm soaks or drenches affect potted gladiolus production. Acta Hort. 1104: 103-108.

Barrett J., Bartuska C., 2010. Multiple Topflor drenches for baskets. Greenhouse Product News 10: 23-25.

BASRAA.S., 2000. Plant Growth Regulators in Agriculture and Horticulture. Their Role and Commercial Uses. The Haworth Press Inc., Binghamton, NY, USA.

Bisi-Johnson M.A., OBi C. L. Hattori T., Oshima Y., Li S., Kambizi L. et al., 2011. Evaluation of the antibacterial and anticancer activities of some South African medicinal plants. BMC Complement. Altern. Med. 11:14.

Carlson A.S., Dole J.M., Whipker B.E., 2015. Plant growth regulator drenches suppress foliage and inflorescence height of 'Leia' pineapple lily. HortTechnology 25: 105-109.

De Hertogh A., Le Nard M., 1993. General chapter on summer flowering bulbs. In: The Physiology of Flower Bulbs. De Hertogh A. and Le Nard M. (eds), Elsevier Science Publishers, Amsterdam, London: 752-754.

Filios P.M., Miller W.B., 2013. Effects of flurprimidol, paclobutrazol and uniconazole drenches on Eucomis comosa growth. Acta Hort. 1002: 439-443.

Fitchet M., van De Venter H.A., 1988. Rapid vegetative propagation of pineapples by crown sectioning. S. Afr. J. Plant Soil 5: 27-31.

Gaussoin R.E., Branham B.E., Flore J.A., 1997. Carbon dioxide exchange rate and chlorophyll content of turfgrasses treated with flurprimidol or mefluidide. J. Plant Growth Regul. 16: 73-78.

Grossman K., 1992. Plant growth retardants: Their mode of action and benefit for physiological research. In: Progress in Plant Growth Regulation. C.M. Karssen, L.C. van Loon and D. Vreugdenhil (eds), Kluwer Academic Publishers, Dordrecht: 788-797.

Hashemabadi D., Lipaei S.R., Shadparvar V., Zarchini M., Kaviani B., 2012. The effect of cycocel and daminozide on some growth and flowering characteristics of Calendula officinalis L., an ornamental and medicinal plant. J. Med. Plant Res. 6: 1752-1757.

Ilczuk A., Winkelmann T., Richartz S., Witomska M., SEREK M., 2005. In vitro propagation of Hippeastrum 
$\times$ chmielii Chm. - Influence of flurprimidol and the culture in solid or liquid medium and in temporary immersion systems. Plant Cell Tissue Organ Cult. 83: 339-346.

KApCZyŃSKa A., Malik M., 2016. Planting time and flurprimidol treatment influence the growth and flowering of Lachenalia. HortTechnology 26: 293298.

Kazaz S., Askin M.A., Kilic S., Ersoy N., 2010. Effects of day length and daminozide on the flowering, some quality parameters and chlorophyll content of Chrysanthemum morifolium Ramat. Sci. Res. Essays 5: 3281-3288.

Luria G., Ziv O., Weiss D., 2011. Effects of temperature, day length and light intensity on Eucomis development and flowering. Acta Hort. 886: 167-174.

Masondo N.A., Aremu A.O., Finnie J.F., van Staden J., 2014a. Plant growth regulator induced phytochemical and antioxidant variations in micropropagated and acclimatized Eucomis autumnalis subspecies autumnalis (Asparagaceae). Acta Physiol. Plant. 36: 2467-2479.

Masondo N.A., Finnie J.F., van Staden J., 2014 b. Pharmacological potential and conservation prospect of the genus Eucomis (Hyacinthaceae) endemic to southern Africa. J. Ethnopharmacol. 151: 44-53

Ndhlala A.R., Mulaudzi R.B., Kulkarni M.G., van Staden J., 2012. Effect of environmental factors on seedling growth, bulb development and pharmacological properties of medicinal Eucomis autumnalis. S. Afr. J. Bot. 79: 1-8.

Pobudkiewicz A., Treder J., 2006. Effects of flurprimidol and daminozide on growth and flowering of oriental lily 'Mona Lisa'. Sci. Hortic. 110: 328-333.

RADEMACHER W., 2000. Growth retardants: Effects on gibberellins biosynthesis and other metabolic pathways. Annu. Rev. Plant Phys. 51: 501-531.

RADEMACHER W., 2015. Plant growth regulators: Backgrounds and uses in plant production J. Plant Growth Regul. 34: 845-872.

Salachna P., Grzeszczuk M., Wilas J., 2015 a. Total phenolic content, photosynthetic pigment concentration and antioxidant activity of leaves and bulbs of selected Eucomis L'Hér. taxa. Fresen. Environ. Bull. 24: 4220-4225.
SAlachna P., ZawadziŃSKA A., 2013. The effects of flurprimidol concentrations and application methods on Ornithogalum saundersiae Bak. grown as a pot plant. Afr. J. Agric. Res. 8: 6625-6628.

Salachna P., Zawadzinska A., Wilas J., 2015b. The use of natural polysaccharides in Eucomis autumnalis propagation by twin-scale cuttings. Acta Hort. 1104: 225-227.

SprZĄCZKA I., LASKOWSKA H., 2013. Evaluation of flurprimidol efficiency in pot cultivation of forced tulips. Acta Sci. Pol., Hortorum Cultus 12: 25-33.

Sun T., Kamiya Y., 1994. The Arabidopsis GA1 locus encodes the cyclase ent-kaurene synthetase A of gibberellin biosynthesis. Plant Cell 6: 1509-1518.

TAHA R.A., 2012. Effect of some growth regulators on growth, flowering, bulb productivity and chemical composition of iris plants. J. Hort. Sci. Ornamen. Plants 4: 215-220.

TAYlor J.L.S., van Staden J., 2001. The effect of age, season and growth conditions on anti-inflammatory activity in Eucomis autumnalis (Mill.) Chitt. plant extracts. Plant Growth Regul. 34(1): 39-47.

Whipker B.E., McCall I., Buhler W., Krug B., 2011. Flurprimidol preplant soaks and substrate drenches control excessive growth of forced bulbs. Acta Hort. 886: 385-392.

Zawadzińska A., Żurawik P., Salachna P., Dobrowolska A., 2013. Controlling the growth and flowering of seed-propagated geranium (Pelargonium $\times$ hortorum LH Bailey) cultivated in two organic media. EJPAU 5(2), \#3. Available online at http:// http://www.ejpau.media.pl/volume16/issue4/abs-10. html.

Zheng R-R, Wu Y, XIA Y-P., 2012. Chlorocholine chloride and paclobutrazol treatments promote carbohydrate accumulation in bulbs of Lilium Oriental hybrid 'Sorbonne'. J. Zhejiang Univ. Sci. B 13: 136-144.

Zonneveld B.J.M., Duncan G.D., 2010. Genome sizes of Eucomis L'Hér. (Hyacinthaceae) and a description of the new species Eucomis grimshawii G.D.Duncan \& Zonneveld. Plant Syst. Evol. 284: 99-109.

Received September 7, 2016; accepted December 12, 2016 